Original Article

\title{
Histopathological spectrum of salivary gland lesions in rural India
}

\author{
Deepu Mathew Cherian ${ }^{1}$, Rahul M Jadhav ${ }^{1}$, Shaikh Murtuza ${ }^{1}$, Tooba Fatima ${ }^{1}$, \\ Kashinath S Bhople ${ }^{1}$ \\ ${ }^{1}$ Department of Pathology, Indian Institute of Medical Science and Research, Jalna, Maharashtra, India
}

\section{Keywords: \\ Mucoepidermoid carcinoma; Pleomorphic adenoma; Parotid gland; Sialadenitis;}

\begin{abstract}
Background: Salivary gland lesions are of a wide spectrum and affect all the major and minor salivary glands in varying proportions. This study, performed in a rural medical college in Maharashtra, India is intended to see the histopathologic spectrum of salivary gland lesions in the rural population and how it is related to the data from other parts of the country and of the world.

Materials and Methods: This is a retrospective study done in the Department of Pathology of a rural-based medical college, Indian Institute of Medical Science and Research, Warudi, Maharashtra, India for a period of 6 years, from January 2014 to January 2020. Age, sex, location of the lesion, gross and microscopic findings were noted.

Results: A total of 71 lesions were received in the department of pathology during this period. Samples were received from age 11 years to 75 years. Female preponderance with a male: female ratio of $1: 1.15$ was seen. $57.7 \%(n=41)$ were benign, $15.5 \%(n=11)$ were malignant and the rest $(n=19)$ were inflammatory in nature. A maximum number of lesions $(50.7 \%)$ were detected in the Parotid gland. The most common lesion seen was Pleomorphic adenoma $(36.62 \%, \mathrm{n}=26)$ and the most common malignant lesion was Mucoepidermoid carcinoma.

Conclusions: Present study showed benign and non-neoplastic lesions outnumbering the malignant lesions, with female predominance, and a low mean age for malignant lesions of 38.2years. Comparison with other studies within and outside India showed a similar pattern of distribution of salivary gland lesions in the rural population
\end{abstract}

\section{Correspondence:}

Dr. Deepu Mathew Cherian, MD

Department of Pathology,

Indian Institute of Medical Science and Research, Jalna,

Maharashtra, India

ORCID ID: 0000-0002-6009-9917

Email: deepumathewdmc@gmail.com

Received : October $23^{\text {rd }} 2020$; Accepted : February $15^{\text {th }} 2021$

Citation: Cherian DM, Jadhav RM, Murtuza S, Fatima T, Bhople KS. Histopathological Spectrum of Salivary Gland Lesions in Rural India. J Pathol Nep 2021;11:1830-6. DOI: 10.3126/jpn.v11i1.32442

Copyright: This is an open-access article distributed under the terms of the Creative Commons Attribution 4.0 International License, which permits unrestricted use, distribution, and reproduction in any medium, provided the original author and source are credited.

\section{INTRODUCTION}

The salivary gland has the necessitous function of secreting saliva, which is not only helpful in digestion but also; lends a hand in protecting the body by producing antibodies. Its contribution to smooth speech and mastication also is inevitable.

Salivary gland lesions are peculiar in the sense that they show wide variation in their morphology between various salivary gland lesions. Variation of the morphology within a tumour, variation in morphology among different tumours and less number of articles regarding salivary gland lesion from India at times leads to diagnostic dilemma in the case of reporting salivary gland tumours. ${ }^{1,2}$ 
Nonneoplastic lesions are mainly because of inflammatory or obstructive processes. It can mimic neoplasm as many of them can present clinically as mass lesions. ${ }^{3}$ If we take the neoplastic lesions, around $6.5 \%$ of neoplasms from the head and neck region arise from the salivary gland. $40 \%$ of these turn out to be malignant.4 Salivary gland tumours account for less than $1 \%$ of all tumours. ${ }^{5}$

\section{MATERIALS AND METHODS}

This is a retrospective study carried out in the Department of Pathology of a rural-based medical college, Indian Institute of Medical Science and research, Warudi, Jalna, Maharashtra, India for a period of 6 years, from January 2014 to January 2020 . A total of 71 salivary gland specimens were received in the department of pathology during this period. All the specimens were received in $10 \%$ neutral buffered formalin. The specimens were processed, and the sections were stained with haematoxylin and eosin. Special stains were done whenever needed.

Lesions from parotid, submandibular and minor salivary glands were included in the study. Information regarding age, sex, clinical presentation, gross and microscopic description, and final diagnosis were recorded from the histopathology register. Formal written informed consent was not required as the study was from the data collected from the departmental register.

\section{RESULTS}

A total of 71 lesions were received in the department of pathology during this period. Samples were received from age 11 years to 75 years. Female preponderance with a male: female ratio of $1: 1.15$ was seen. $57.7 \%(n=41)$ were benign, $15.5 \%(\mathrm{n}=11)$ were malignant and the rest $(\mathrm{n}=19)$ were inflammatory in nature. The maximum number of lesions $(50.7 \%)$ was detected in the parotid gland. Basal cell adenoma $(\mathrm{n}=8)$ ) was found only in females while Warthin tumour $(\mathrm{n}=3)$ was found only in males. The most common lesion was Pleomorphic Adenoma which accounted for $36.62 \%(n=26)$. The most common malignant lesion was Mucoepidermoid carcinoma which accounted for 9.86\% $(n=7)$ of all cases and $63.64 \%$ of all malignant cases (Table 1).

Age group 11-20, 21-30, 31-40 years had the maximum number of cases, 15 each. The most common lesion in the age group of 21-30 was sialadenitis and the most common lesion above 60 years of age was mucoepidermoid carcinoma. In all other age groups, the most common lesion was Pleomorphic adenoma (Table 2).

Basal cell adenoma $(n=8)$, ductal cell adenoma $(n=1)$, mucocele $(\mathrm{n}=1)$, and oncocytosis $(\mathrm{n}=1)$ were found only in females while Warthin tumour $(\mathrm{n}=3)$ and lymphoepithelial cyst $(\mathrm{n}=1)$ was found only in males (Table 3 ).
$50.7 \%(\mathrm{n}=36)$ lesions were detected in the parotid gland, $26.8 \%(\mathrm{n}=19)$ cases were from submandibular glands, $9.8 \%$ $(\mathrm{n}=7)$ cases were from minor salivary glands. $12.7 \%(\mathrm{n}=9)$ had no site mentioned in the records (Table 4).

In the parotid gland, $63.9 \%(\mathrm{n}=23)$ cases were benign, $22.2 \%$ $(n=8)$ were malignant and $13.9 \%(n=5)$ were inflammatory. The most common benign lesion in the Parotid was Pleomorphic Adenoma which accounted for $38.9 \%(n=14)$ of cases in the parotid. The most common malignant lesion in the parotid was Mucoepidermoid carcinoma which accounted for $16.7 \%(n=6)$ of cases in the parotid (Table 4$)$.

In the submandibular gland, $63.2 \%(\mathrm{n}=12)$ cases were inflammatory, 26.3\% $(n=12)$ were benign and $10.5 \%(n=2)$ were malignant. The most common lesion encountered in the submandibular gland was sialadenitis which accounted for $63.2 \%(n=12)$ cases. The only malignant lesion reported in a submandibular gland in the present study was adenoid cystic carcinoma which accounted for $10.5 \%(n=2)$ of cases in submandibular glands (Table 4).

In the minor salivary glands, $71.4 \%(\mathrm{n}=5)$ cases were benign, $14.3 \%(\mathrm{n}=1)$ cases were inflammatory, and $14.3 \%$ $(\mathrm{n}=1)$ cases were malignant. The most common lesion was pleomorphic adenoma which accounted for $28.6 \%(n=2)$ cases. The one malignant lesion from a minor salivary gland that was reported in this study was mucoepidermoid carcinoma (Table 4).

The most common site for an inflammatory lesion in the present study was the submandibular gland $63.2 \%(n=12)$ of inflammatory cases were from submandibular glands. The most common site of benign and malignant lesion was the

\begin{tabular}{|c|c|c|}
\hline Diagnosis & $\begin{array}{l}\text { No. of } \\
\text { cases }\end{array}$ & $\begin{array}{c}\text { Percentage } \\
(\%)\end{array}$ \\
\hline Mucoepidermoid carcinoma & 7 & 9.86 \\
\hline Acinic cell carcinoma & 1 & 1.41 \\
\hline Adenoid cystic carcinoma & 2 & 2.82 \\
\hline Squamous Cell Carcinoma & 1 & 1.41 \\
\hline Pleomorphic adenoma & 26 & 36.62 \\
\hline Basal cell adenoma & 8 & 11.27 \\
\hline Warthin tumor & 3 & 4.23 \\
\hline Chronic sialadenitis & 15 & 21.13 \\
\hline Sialadenitis with sialolithiasis & 2 & 2.82 \\
\hline Sialadenitis with mucocele & 1 & 1.41 \\
\hline Ductal cell adenoma & 1 & 1.41 \\
\hline Lymphoepithelial cyst & 1 & 1.41 \\
\hline Mucocele of parotid & 1 & 1.41 \\
\hline Necrotising granulomatous inflammation & 1 & 1.41 \\
\hline Oncocytic metaplasia & 1 & 1.41 \\
\hline Total & 71 & 100 \\
\hline
\end{tabular}


Table 2: Age-wise distribution of various salivary gland lesions among the study population

\begin{tabular}{lcc}
\hline Age group & Total no. of cases & Most common lesion \\
\hline $\mathbf{1 1 - 2 0}$ & 15 & Sialadenitis and Pleomorphic adenoma $(\mathrm{n}=5)$ \\
$\mathbf{2 1 - 3 0}$ & 15 & Sialadenitis $(\mathrm{n}=8)$ \\
$\mathbf{3 1 - 4 0}$ & 15 & Pleomorphic adenoma $(\mathrm{n}=9)$ \\
$\mathbf{4 1 - 5 0}$ & 12 & Pleomorphic adenoma $(\mathrm{n}=4)$ \\
$\mathbf{5 1 - 6 0}$ & 9 & Pleomorphic adenoma and Basal cell adenoma $(\mathrm{n}=2)$ \\
$>\mathbf{6 0}$ & 5 & Mucoepidermoid carcinoma $(\mathrm{n}=2)$
\end{tabular}

Table 3: Sex wise distribution

\begin{tabular}{|lcc|}
\hline Type of Lesion & Males & Females \\
\hline Inflammatory & 8 & 11 \\
\hline Benign & 19 & 22 \\
\hline Pleomorphic adenoma & 15 & 11 \\
\hline Warthin tumour & 3 & 0 \\
\hline Lymphoepithelial cyst & 1 & 0 \\
\hline Basal cell adenoma & 0 & 8 \\
\hline Ductal cell adenoma & 0 & 1 \\
\hline Mucocele of parotid & 0 & 1 \\
\hline Oncocytic metaplasia & 0 & 1 \\
\hline Malignant & 6 & 5 \\
\hline Mucoepidermoid carcinoma & 4 & 3 \\
\hline Acinic cell carcinoma & 1 & 0 \\
\hline Adenoid cystic carcinoma & 1 & 1 \\
\hline Squamous cell carcinoma & 0 & 1 \\
\hline Total cases & $\mathbf{3 3}$ & $\mathbf{3 8}$ \\
\hline
\end{tabular}

parotid gland, $56.1 \%(\mathrm{n}=23)$ and $72.7 \%(\mathrm{n}=8)$ of benign and malignant cases respectively were from the parotid gland. The most common site for pleomorphic adenoma was parotid, 53.8\% $(\mathrm{n}=14)$. Followed by submandibular gland $19.2 \%(\mathrm{n}=5)$ and minor salivary glands $7.7 \%(\mathrm{n}=2)($ Table $4)$.
Warthin tumour $(n=3)$, Squamous cell carcinoma $(n=1)$, mucocele of the parotid $(\mathrm{n}=1)$, and lymphoepithelial cyst $(n=1)$ was found only in the parotid gland. Acinic cell carcinoma ( $n=2$, fig. 1) was reported only from the submandibular gland (Table 4). One case of the necrotizing granulomatous lesion was reported during this period. Ziehl Neelsen stain was done to rule out the tuberculous origin and Periodic acid-Schiff stain was done to see the presence of any fungal organism, both were negative.

\section{DISCUSSION}

Lesions of salivary glands often pose diagnostic dilemmas to the clinician and surgical pathologist. Variable clinical presentation, overlapping morphology, and lack of published data warrant more research in the field of salivary gland pathology. The discovery of tubarial salivary glands ${ }^{6}$ has opened a wider path for research in this area.

The present study had a slight female preponderance with a male: female ratio of $1: 1.15$. A study by Rewsuwan et $\mathrm{al}^{7}$ also reported a female preponderance with a male: female ratio of 1:1.37. This is in contrast to the study conducted by Young Man $\mathrm{Lee}^{8}$ in the Korean population where the male: female ratio was $1.25: 1$. Male: female ratio in a study conducted in Jordan by J K Ma'aita et $\mathrm{al}^{9}$ was 1.6:1.

Table 4: Site wise distribution of Salivary gland lesions

\begin{tabular}{lcccc}
\hline Type of Lesion & Parotid & Submandibular & Minor Salivary Gland & Site not mentioned \\
\hline Inflammatory & 5 & 12 & 1 & 1 \\
\hline Benign & 23 & 5 & 5 & 8 \\
\hline Pleomorphic adenoma & 14 & 5 & 0 & 5 \\
\hline Warthin tumour & 3 & 0 & 0 & 0 \\
\hline Lymphoepithelial cyst & 1 & 0 & 1 & 0 \\
\hline Basal cell adenoma/ monomorphic adenoma & 4 & 0 & 1 & 3 \\
\hline Ductal cell adenoma & 0 & 0 & 0 & 0 \\
\hline Mucocele of parotid & 1 & 0 & 1 & 0 \\
\hline Oncocytic metaplasia & 0 & 0 & 1 & 0 \\
\hline Malignant & 8 & 2 & 1 & 0 \\
\hline Mucoepidermoid carcinoma & 6 & 0 & 0 & 0 \\
\hline Acinic cell carcinoma & 1 & 0 & 0 & 0 \\
\hline Adenoid cystic carcinoma & 0 & 2 & 0 & 0 \\
\hline Squamous cell carcinoma & 1 & 0 & $\mathbf{7}$ & \\
\hline Total & $\mathbf{3 6}$ & $\mathbf{1 9}$ & & \\
\hline
\end{tabular}


Table 5: Benign and Malignant cases in various studies

\begin{tabular}{lcc}
\hline Series & $\begin{array}{c}\text { Benign } \\
\mathbf{( \% )}\end{array}$ & $\begin{array}{c}\text { Malignant } \\
(\mathbf{\%})\end{array}$ \\
\hline Nepal A et $\mathrm{al}^{18}$ from Nepal & 81 & 19 \\
\hline${\text { Bashir et } \mathrm{al}^{10}}^{10}$ from India & 61.25 & 38.75 \\
Vuhahula $^{19}$ from Uganda & 53.4 & 46.6 \\
\hline Ankur and Hinal ${ }^{20}$ from India & 40 & 25 \\
W.M. Tilakaratne et $\mathrm{al}^{21}$ from Sri Lanka & 49.9 & 50.1 \\
Present study & $\mathbf{5 7 . 7}$ & $\mathbf{1 5 . 5}$
\end{tabular}

The studies conducted by Bashir S et a ${ }^{10}$ and Potdar and Paymaster ${ }^{11}$ from India also had a male preponderance.

Benign cases also had a slight female preponderance with $53.66 \%$ of benign cases being reported in females. But malignant cases had a slight male preponderance with $54.54 \%$ of malignant cases being reported in males. This was in concordance with the study conducted by Chatterjee et $\mathrm{al}^{12}$ who reported $54.3 \%$ benign cases occurring in females and $52.8 \%$ of malignant cases occurring in males.

Li Long-Jiang et al ${ }^{13}$ conducted a 50 -year study in West China in which 3461 cases were studied. In that study, the male: female ratio was $0.99: 1$ in the benign cases and 1.34:1 in the malignant cases which are in compliance with the present study where the male: female ratio for benign cases was $0.86: 1$ and male: female ratio of malignant cases was 1.2:1.

Basal cell adenoma (fig. 2) was seen only in females in the present study. This is in accordance with the epidemiology of Basal cell adenoma mentioned in the 2017 edition WHO Classification of Head and Neck Tumours 14 where they have mentioned female dominance. Viswanathan et al ${ }^{15}$ also reported a male: female ratio of 2:1 for Basal cell adenoma.

Warthin tumour was found only in males. This is substantiating the proven fact that the Warthin tumour has a male preponderance. Bobati et al ${ }^{16}$ also reported that in their study, the Warthin tumour was found only in males. Tian et a ${ }^{17}$ reported that $92 \%$ of Warthin tumour cases were found in males.

Out of the 71 cases studied, $57.7 \%(\mathrm{n}=41)$ were benign
$15.5 \%(\mathrm{n}=11)$ were malignant and the rest $26.8 \%(\mathrm{n}=19)$ were of inflammatory nature. The values are comparable with the studies conducted by Nepal A et $\mathrm{al}^{18}$, and Bashir et al. ${ }^{10}$ A study conducted by Vuhahula ${ }^{19}$ in Uganda had a higher incidence of malignant lesions. A study by Ankur and Hinal et $\mathrm{al}^{20}$ reported a higher incidence of non-neoplastic lesions compared to the present study (Table 5). A study by W.M. Tilakaratne et $\mathrm{al}^{21}$ from Sri Lanka showed an equal proportion of benign and malignant lesions.

From this, we can conclude that there is a wide variation in the proportion of benign and malignant lesions in various geographical areas. The present study had a low percentage of malignant lesions probably because the study included inflammatory lesions as a $3^{\text {rd }}$ entity other than benign and malignant lesions.

The cases studied belonged to the age group of 11 years to 75 years with a mean age of 36.9 years. The study by Bashir et $\mathrm{al}^{10}$ also had a similar age group. Benign cases had a mean age of presentation of 39.68 years, and malignant cases had a mean age of 38.2 years in the present study. A study by Bashir et al ${ }^{10}$ had a comparable mean age of benign cases but a higher mean age for malignant cases which was 51.54 years. The mean age was more comparable with the study conducted by Potdar and Paymaster ${ }^{11}$ who reported a mean age of 40.1 years and 46.3 years for benign and malignant cases respectively and with Li Long-Jiang et $\mathrm{al}^{13}$ in whose study, the average ages were 41.38 years for the benign cases and 45.20 for the malignant cases.

Most numbers of lesions were diagnosed in the parotid gland $(50.7 \%)$ followed by submandibular glands $(26.8 \%)$ and minor salivary glands $(9.8 \%)$. No cases were reported from the sublingual salivary gland. A similar pattern was seen in other studies (Table6).

Tumours of sublingual glands are rare. Only $0.5-1 \%$ of epithelial salivary gland neoplasm arises from the sublingual gland. $70-90 \%$ of sublingual tumours are malignant. ${ }^{24}$ Goode et $\mathrm{al}^{25}$ studied mucoepidermoid carcinoma of salivary glands and found that only 3\% was diagnosed in sublingual glands.

Pleomorphic adenoma was the most common lesion

Table 6: Site distribution of major salivary tumours in different studies

\begin{tabular}{|c|c|c|c|c|}
\hline Series & Parotid gland (\%) & $\begin{array}{l}\text { Submandibular } \\
\text { gland }(\%)\end{array}$ & Sublingual gland (\%) & $\begin{array}{c}\text { Minor salivary } \\
\text { gland }(\%)\end{array}$ \\
\hline Bashir $S$ et al ${ }^{10}$ from India & 65 & 25 & 0.0 & 10 \\
\hline Richardson et al $^{23}$ from USA & 82.5 & 9.3 & 0.0 & 8.2 \\
\hline Rewsuwan et al $^{7}$ from Thailand & 80.11 & 15.34 & 1.14 & 3.41 \\
\hline Vuhahula et al ${ }^{19}$ from Uganda & 34 & 33.2 & 0.0 & 32.8 \\
\hline M Gao et $\mathrm{al}^{22}$ from China & 62.66 & 9.92 & 2.57 & 24.85 \\
\hline J K Ma'aita et al' from Jordan & 70.2 & 10.4 & 0.4 & 19 \\
\hline Present study & 50.7 & 9.8 & 0.0 & 9.8 \\
\hline
\end{tabular}




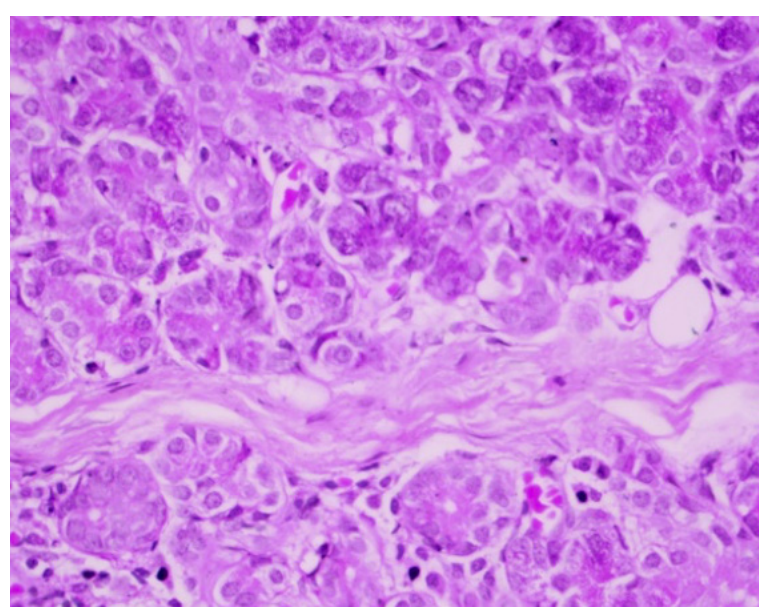

Figure 1: Acinic cell carcinoma of Parotid gland showing solid and trabecular arrangement of acinar cells with basophilic granular cytoplasm. (HE stain, x400)

encountered in the present study. The data from various literatures showed that this is the world-wide epidemiological trend. Young Man Lee ${ }^{8}$ from Korea, Li Long-Jiang et al ${ }^{13}$ from West China, Vargas et $\mathrm{al}^{26}$ from Brazil, Chatterjee et $\mathrm{al}^{12}$ from India, A.G.Hill ${ }^{27}$ from Kenya, Eveson et al28 from the UK, and Richardson et $\mathrm{a}^{23}$ from the USA, J K Ma'aita et $\mathrm{al}^{9}$ from Jordan, E C Otoh et al from Nigeria, W. M. Tilakaratne et $\mathrm{a}^{21}$ from Sri Lanka, all showed similar data. A study by Dong Hoon Lee et $\mathrm{al}^{29}$ showed that pleomorphic adenoma is the most common lesion even in the paediatric population.

Pleomorphic adenoma had a male preponderance. Male: Female ratio was 1.36:1. The percentage of males affected was less compared to other studies like Bashir $\mathrm{S}$ et $\mathrm{al}^{10}$ and Vargas et $a l^{26}$ whose study reported male to female ratio of $2.6: 1$ and $2: 1$ respectively

Salivary gland diseases are not quite common in the paediatric age group. Mucocele is the most common lesion seen in this age group. Mumps is the most common cause of sialadenitis in children. The most common salivary gland tumour in paediatric population is pleomorphic adenoma. ${ }^{30}$

Paediatric age group cases encountered in the present study were 9 cases $(12.67 \%)$. The cases were found in the age ranging from 11 years to 18 years with an average age of 14.9 years. Male: Female ratio was 1:1.25, showing a slight female preponderance. 4, 3, and 1 case were reported from Parotid, Submandibular, and Minor salivary glands, respectively. 1 case had no site mentioned in the records.

Out of the 9 cases, 2 cases were malignant, 3 were inflammatory lesions and 4 were benign lesions. The most common lesion in this age group was pleomorphic adenoma $(n=3)$. Malignant cases reported were Mucoepidermoid carcinoma and Adenoid cystic carcinoma. According to the study by Heinrich et al (31), the most common paediatric salivary gland malignant lesion is mucoepidermoid

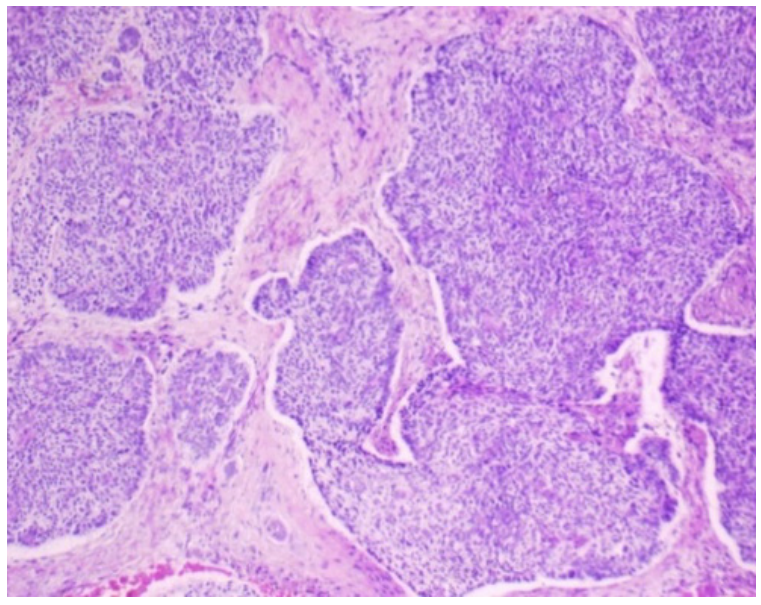

Figure 2: Basal Cell Adenoma showing solid and trabecular growth of epithelial cells with peripheral palisading in a fibrous stroma. (HE stain, x100)

carcinoma followed by acinic cell carcinoma and adenoid cystic carcinoma.

The most common malignant lesion was mucoepidermoid carcinoma which accounted for $63.63 \%(n=7)$ of all malignant cases and $9.86 \%$ of all the cases studied. This is comparable with the study conducted by Archana Shetty et $\mathrm{al}^{32} \mathrm{Achalkar}^{33}$ Ankur and Hinal et al 20 and $\mathrm{Hill}^{27}$ who reported $12.5 \%, 12.9 \%, 8.33 \%$, and $13.6 \%$ of cases as mucoepidermoid carcinoma (Table 9). Tilakaratne et $\mathrm{al}^{21}$ reported a slightly increased incidence of mucoepidermoid carcinoma of $21.6 \%$. Dong Hoon Lee et $\mathrm{al}^{29}$, in their study on paediatric parotid tumours, stated that the most common malignancy among paediatric population is mucoepidermoid carcinoma. But other studies by Vuhahula ${ }^{19}$, Rewsuwan et $\mathrm{al}^{7}$, Chatterjee et $\mathrm{al}^{12}$, and Bobati et $\mathrm{al}^{16}$ reported Adenoid cystic carcinoma as the most common malignant lesion. Young Man Lee et $\mathrm{al}^{8}$ reported squamous cell carcinoma as the most common malignant lesion in their study which is in contrast to most of the previous studies.

The most common location of mucoepidermoid carcinoma was the parotid gland $(85.71 \%$ of cases) followed by the minor salivary gland $(14.29 \%$ of cases). This data is in accordance with the study conducted by Bashir $\mathrm{S}$ et a ${ }^{10}$ who reported that in their study, $71 \%$ of cases were reported from parotid and $21.42 \%$ cases from minor salivary glands.

The mean age for mucoepidermoid carcinoma in the present study was 38.5 years. Vargas et $\mathrm{al}^{26}$ also reported a mean age of 37.92 while Bashir $\mathrm{S}$ et al10 reported a higher mean age of 53.92 years. The most common malignant lesion in the minor salivary gland was Adenoid cystic carcinoma $(n=2)$. This was the only malignant lesion reported from submandibular gland in the present study. The findings were similar to the study conducted by Bashir $\mathrm{S}$ et $\mathrm{al}^{10}$, Rewsuwan et $\mathrm{al}^{7}$, Richardson et $\mathrm{al}^{23}$, and Potdar et al. ${ }^{11}$

The average size of the salivary gland lesion received for 
histopathology examination was $2.97 \mathrm{~cm} .46 .5 \%(\mathrm{n}=33)$ cases were having a size of less than $3.0 \mathrm{~cm}$. Spiro et al ${ }^{34}$ also reported that $40 \%$ of lesions were below $3.0 \mathrm{~cm}$. The majority of cases were from the size range 3 to $6 \mathrm{~cm}$ which accounted for $50.7 \%(\mathrm{n}=36)$. This is a higher value compared to the study by Spiro et al ${ }^{34}$ who reported that $34 \%$ of cases were in the size range of 3 to $6 \mathrm{~cm}$. The average size of the benign lesion was 2.75 and the average size of the malignant lesion was $3.32 \mathrm{~cm}$. Rewsuwan et $\mathrm{al}^{7}$ also reported that malignant lesions were having a larger average size than benign ones.

\section{CONCLUSIONS}

The study on the histopathologic spectrum of salivary gland tumours in rural populations showed a similar spectrum compared to the urban population. Benign and nonneoplastic lesions are outnumbering the malignant lesions. Overall, a female predominance was seen but the malignant lesions showed male preponderance. A low mean age of 38.2 years for malignant lesions is alarming and needs further research to substantiate the cause.

\section{Acknowledgment}

We sincerely thank Honourable Dean Dr. A. B Solepure and the Head of the Department of Pathology Dr. K. S. Bhople for their constant support and guidance.

\section{Conflict of Interest: None}

\section{REFERENCES}

1. Pachori G, Chandra S, Bihari NA et al. Histopathological spectrum of salivary gland lesions in Ajmer region, Rajasthan, India. Int J Res Med Sci. 2019 Jun 28;7:2708.

2. Venkata $\mathrm{V}$, Irulandy $\mathrm{P}$. The frequency and distribution pattern of minor salivary gland tumors in a government dental teaching hospital, Chennai, India. Oral Surgery, Oral Med Oral Pathol Oral Radiol Endodontology. 2011;111. Crossref

3. Mohan H, Tahlan A, Mundi I et al. Non-neoplastic salivary gland lesions: A 15-year study. Eur Arch Oto-Rhino-Laryngology [Internet]. 2011;268:1187-90. Crossref

4. Viswanathan K, Sung S, Scognamiglio T et al. The role of the Milan System for Reporting Salivary Gland Cytopathology: A 5-year institutional experience. Cancer Cytopathol. 2018;126:541-51. $\underline{\text { Crossref }}$

5. Vicente OP, Marqués NA, Aytés LB et al. Minor salivary gland tumors: A clinicopathological study of 18 cases. Med Oral Patol Oral Cir Bucal. 2008;13:582-8. Crossref

6. Valstar MH, de Bakker BS, Steenbakkers RJHM et al. The tubarial salivary glands: first description of a potential new organ at risk for head-neck radiotherapy. Radiother Oncol. 2020; $\underline{\text { Crossref }}$

7. Mahanupab P, Rewsuwan S, Settakorn J. Salivary gland tumors in maharaj nakorn chiang mai hospital: a retrospective study of 198 cases. Vol. 45, Chiang Mai Med Bull. 2006. Website

8. Lee YM, Choi HJ, Kim JW et al. Parotid gland tumors in a korean population. J Craniofac Surg. 2012;23:e205-9. Crossref

9. Ma'aita JK, Al-Kaisi N, Al-Tamimi S et al. Salivary gland tumors in Jordan: a retrospective study of 221 patients. Croat Med J. 1999;40:539-42. Website
10. Bashir S, Mustafa F, Malla HA, Khan AH, Rasool M, Sharma S. Histopathological spectrum of salivary gland tumors: A 10 year experience. Sch J App Med Sci. 2013;1(6):1070-4. Website

11. Potdar GG, Paymaster JC. Tumors of the salivary glands. Am J Surg. 1969;118:440-7. $\underline{\text { Crossref }}$

12. Chatterjee $t$, panda $p$. A pathological study of benign and malignant tumours of salivary glands. Med J Armed Forces India. 2000;56:2826. Crossref

13. Li L jiang, Li Y, Wen Y ming et al. Clinical analysis of salivary gland tumor cases in West China in past 50 years. Oral Oncol. 2008;44:18792. $\underline{\text { Crossref }}$

14. Katabi, Nora, and James S. Lewis. "Update from the 4th Edition of the World Health Organization Classification of Head and Neck Tumours: What Is New in the 2017 WHO Blue Book for Tumors and Tumor-Like Lesions of the Neck and Lymph Nodes." Head and Neck Pathology 11.1 (2017): 48-54. Crossref

15. Rajasenthil V, Ravi A. Basal Cell Adenoma of the Parotid Gland-A Rare Entity. Indian J Surg. 2014;76:408-10. Crossref

16. Bobati SS, Patil B V., Dombale VD. Histopathological study of salivary gland tumors. J Oral Maxillofac Pathol. 2017;21:46-50. $\underline{\text { Crossref }}$

17. Tian Z, Li L, Wang L, Hu Y, Li J. Salivary gland neoplasms in oral and maxillofacial regions: a 23-year retrospective study of 6982 cases in an eastern Chinese population. Int J Oral Maxillofac Surg. 2010;39:235-42. $\underline{\text { Crossref }}$

18. A Nepal, S T Chettri, R R Joshi et al. Primary salivary gland tumors in eastern Nepal tertiary care hospital. J Nepal Health Res Counc. 2010;8:31-4. Website

19. Vuhahula EA. Salivary gland tumors in Uganda: clinical pathological study. Afr Health Sci. 2004;4:15-23. Website

20. Bobati SS, Patil B V., Dombale VD. Histopathological study of salivary gland tumors. J Oral Maxillofac Pathol. 2017;21:46-50. Crossref

21. Tilakaratne WM, Jayasooriya PR, Tennakoon TM et al. Epithelial salivary tumors in Sri Lanka: A retrospective study of 713 cases. Oral Surgery, Oral Med Oral Pathol Oral Radiol Endodontology. 2009;108:90-8. Crossref

22. Gao M, Hao Y, Huang MX et al. Salivary gland tumours in a northern Chinese population: a 50-year retrospective study of 7190 cases. Int J Oral Maxillofac Surg. 2017;46:343-9. Crossref

23. Richardson GS, Dickason WL, Gaisford JC et al. Tumors of salivary glands: An analysis of 752 cases. Plast Reconstr Surg. 1975;55:1318. $\underline{\text { Crossref }}$

24. Kumar N A, Nair PP, Thomas S et al. Mucoepidermoid carcinoma of sublingual gland: A malignant neoplasm in an uncommon region. BMJ Case Rep.2011. Crossref

25. Goode RK, Auclair PL, Ellis GL. Mucoepidermoid carcinoma of the major salivary glands: Clinical and histopathologic analysis of 234 cases with evaluation of grading criteria. Cancer. 1998;82:1217-24. Crossref

26. Vargas PA, Gerhard R, Araújo Filho VJF et al. Salivary gland tumors in a Brazilian population: a retrospective study of 124 cases. Rev Hosp Clin Fac Med Sao Paulo. 2002;57:271-6. $\underline{\text { Crossref }}$

27. Hill AG. Major salivary gland tumours in a rural Kenyan hospital. East Afr Med J. 2002;79:8-10. $\underline{\text { Crossref }}$

28. Eveson JW, Cawson RA. Salivary gland tumours. A review of 2410 cases with particular reference to histological types, site, age and sex distribution. J Pathol. 1985;146:51-8. $\underline{\text { Crossref }}$

29. Lee DH, Yoon TM, Lee JK, Lim SC. Clinical features of pediatric parotid tumors: 10-year experience of a single institute. Acta Otolaryngol. 2013;133:1213-8. Crossref

30. Carlson ER, Ord RA. Benign Pediatric Salivary Gland Lesions. Vol. 28, Oral and Maxillofacial Surgery Clinics of North America. W.B. 
Saunders; 2016. p. 67-81. Crossref

31. Iro H, Zenk J. Salivary gland diseases in children. GMS Curr Top Otorhinolaryngol Head Neck Surg. 2014;13. Website

32. Shetty A. Spectrum of Major Salivary Gland Tumours: Clinicopathologic Study. Sch J Appl Med Sci SJAMS. 2014;2:108890. Website
33. Achalkar G V. A clinicopathological study of salivary gland tumors J Evol Med Dent Sci. 2013 ;2(50):9726-32. Crossref

34. Spiro RH, Huvos AG, Strong EW. Cancer of the parotid gland. A clinicopathologic study of 288 primary cases. Am J Surg. 1975;130(4):452-9. Crossref 